\title{
The Impact of Gambling Gross Income, Unemployment Rate, Money Supply and CPI on Residential Housing Value in Macau: Theory and Evidence
}

\author{
Ting Lan \\ Institute of Accounting and Finance, Beijing Institute of Technology, Zhuhai, China \\ Email: Olivialan1978@sina.com
}

How to cite this paper: Lan, T. (2021). The Impact of Gambling Gross Income, Unemployment Rate, Money Supply and CPI on Residential Housing Value in Macau: Theory and Evidence. Theoretical Economics Letters, 11, 1067-1089. https://doi.org/10.4236/tel.2021.116068

Received: October 9, 2021

Accepted: November 9, 2021

Published: November 12, 2021

Copyright $\odot 2021$ by author(s) and Scientific Research Publishing Inc. This work is licensed under the Creative Commons Attribution International License (CC BY 4.0).

http://creativecommons.org/licenses/by/4.0/

\section{(c) (i) Open Access}

\begin{abstract}
This paper uses the classical and easy-to-understand Vector Auto-regression Model Method to study the impact of economic and monetary policy variables on the residential property market in Macau. By using sample monthly data from Jan. 2005 to May 2021, the empirical results show the dynamic relationship among the residential property value, key economic and monetary variables. Furthermore, adopting the Granger causality test, generalized impulse response function, variance decomposition and co-integration test of the corresponding VAR specification, the tables and graphs clearly explain the residential housing value has a positive relationship with the gambling gross income; it has a negative relationship with the unemployment rate; it has a positive relationship with the money supply; it has a negative relationship with the consumer price index. Finally, this paper gives five policy actions to help government stabilize the residential property market in Macau and make it healthy develop.
\end{abstract}

\section{Keywords}

VAR, Granger Causality Test, Generalized Impulse Response Function, Variance Decomposition and Co-Integration Test

\section{Introduction}

The full name of Macau Special Administrative Region of the People's Republic of China is one of the core cities of the Guangdong-Hong Kong-Macau Greater Bay Area. On December 20, 1999, Macau returned to the embrace of the mo- 
therland. A thriving service sector and light industry have made it one of the most developed regions in the world. However, till the year 2020, there are about 683,100 people living on an island of about 33 square kilometers in Macau, and the population density of 20,000 people per square kilometer is one of the highest in the world. The situation of "land is precious" is quite prominent in Macau. In addition, the per capita GDP is MOP661,000 in the year 2019 and rapid economic development is among the top three in the world. These data sources come from the Statistics and Census Service (DSEC). Many factors work together to make the value of land resources in Macau, the value of houses and buildings and the value of people's investment in labor extremely high. These factors work together to promote the red-hot real estate market in Macau and thus cause the housing price of Macau to soar to the ground.

In Macau Special Administrative Region, the real estate industry is one of the four pillar industries, and the analysis of the regional economy is of certain significance to the study of Macau real estate market. Figure 1 displays Macau's Annual GDP from the year 2000 to the year 2020. Data source on GDP comes from the Statistics and Census Service (DSEC) of Macau. As shown in Figure 1, After Macau returns to China in 1999, Macau's economy turned from a high-speed growth period to stable and sustainable development. Macau's economic boom from 2000 to 2014 depended on the liberalization of gambling in 2002. According to Figure 1, GDP increased eight times from the year 2000's 54,369 million Patacas to the year 2014's 438,516 million Patacas. As one of the world's three major gambling cities, Macau's economic development depends largely on tourism and gambling industries. At the celebration of the $15^{\text {th }}$ anniversary of Macau's return to China, President Xi Jinping stressed that "we should strengthen and improve supervision over the gaming industry, actively foster new economic

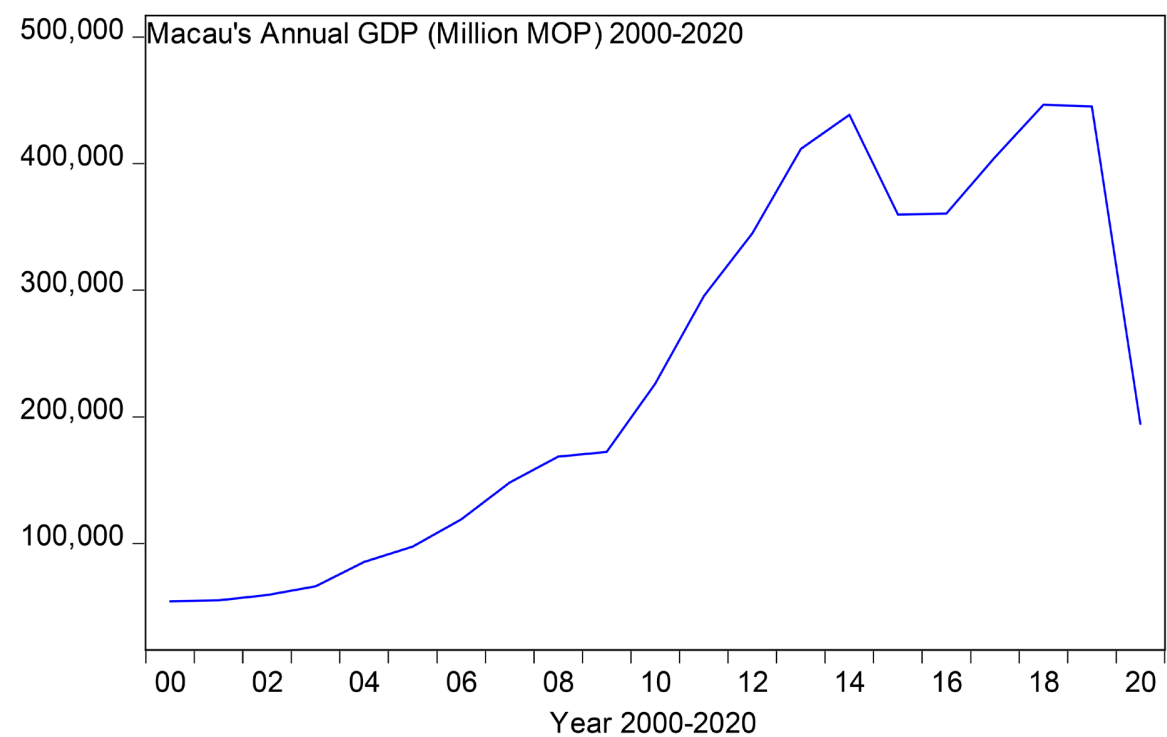

Figure 1. Macau's Annual GDP (2000-2020). Source: Statistics and Census Service (DSEC) of Macau. 
growth points, and constantly promote appropriate diversified and sustainable economic development”. In 2015, Macau's economy took a turning point. The gross income of the gambling industry was 231,811 million Patacas, down $34.3 \%$ year on year, and the gross domestic product also decreased to 359,806 million Patacas. Facing the internal and external difficulties, for the long-term healthy operation of the economy, the development of the depressed gambling industry has been deeply adjusted after the year 2015. The economy gradually improved over the following years. Because of the outbreak of COVID-19 in December 2019, Macau entry passengers plunged, gambling gross income dropped from January 2020's 2022.2 billion Patacas to February 2020's 3.134 billion Patacas, meanwhile, GDP also decreased dramatically in the year 2020, it was only 194,398 million Patacas. After resuming the visitors' visa to Macau gradually in the year 2021, the gross income of the gambling industry rebounded, and the economy gradually recovered.

After it returned to China in 1999, the government gave Macau a few preferential policies. In 2002, the 60-year gaming monopoly system was ended, and the gaming operation rights were opened. Subsequently, the tourism and gambling industries were brilliant, and the economic recovery promoted the development of the real estate industry. Figure 2 displays Macau's residential housing transaction volume from the year 2000 to the year 2020. Data source comes from the Statistics and Census Service (DSEC) of Macau. In 2008, it was temporarily affected by the financial crisis, the transaction volume of residential building units dropped to 13,686 , a year-on-year drop of $36.7 \%$. In 2015 , it was affected by the gambling industry, the economy was depressed. In that year, the transaction volume of residential building units was only 5976, down $21.6 \%$ year on year. In 2019 , in order to celebrate the $20^{\text {th }}$ anniversary of China's return to China, the

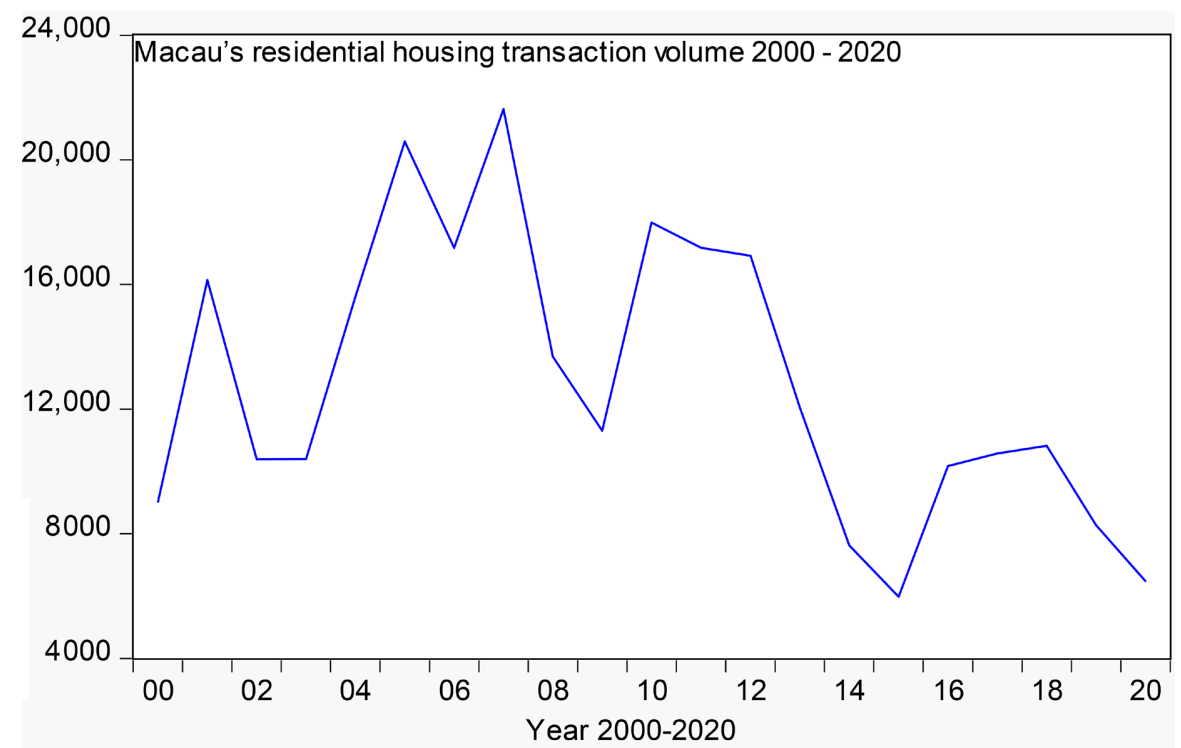

Figure 2. Macau's residential housing transaction volume (2000-2020). Source: Statistics and Census Service (DSEC) of Macau. 
government tightened the policy of entry visa issuance, etc., and the transaction volume of residential buildings and the average property price declined simultaneously, showing a slowing trend. Affected by the epidemic, the transaction volume in February 2020 dropped sharply, down $48.4 \%$ year on year. In the first half of the year 2020, the real estate market was depressed. The transaction volume was only 6483 in the year 2020. In the first half of the year 2021, the anti-epidemic effect was achieved, the transaction volume rebounded, and the housing demand was gradually released.

Tourism also plays a decisive role in Macau's economy. Many tourists enter and leave Macau every day, which has led to the rapid development of Macau's gambling industry. When tourists spend money and stay in Macau, they also promote the development of Macau's tourism and catering industries. In 2020, the COVID-19 epidemic was prevalent. According to the data disclosed by the Public Security Police Department of the Macau SAR Government on January 13, 2021, the number of entry-exit persons in Macau in 2020 was 69.55 million, among which only 5.917 million were incoming passengers, which decreased by 64.2\% and 85\% respectively. According to the Public Security Police Department, under the influence of the COVID-19 epidemic in 2020, the number of inbound and outbound people in Macau showed a big decline. At the same time, Macau's economy also suffered a huge blow; the average residential housing value also had been affected. According to the Macau Statistics Bureau, under the condition of COVID-19 gradually improving in the second half of 2020, the number of inbound and outbound visitors in Macau gradually rose to a historical peak, and the hotel occupancy rate gradually rose to $53.1 \%$ from the lowest $11.8 \%$.

Based on the above regional economic analysis, I found the real estate market is one of the main industries in Macau, there is a very important relationship among gambling gross income, GDP, residential housing value and transaction volume. The objective of this study is to use several popular and available economic and monetary policy data in assessing current residential housing value, which could be applicable to the case of Macau. The fundamental variables such as gambling gross income, unemployment rate, money supply, and consumer price index are highlighted as leading impact factors of long-term trends of residential housing value. This paper draws on the research experience of the past scholars, combines the historical data of Macau Statistics and Census Service (DSEC) and the Qianzhan database, it takes the above five factors as the main research objectives, and then makes an empirical analysis. Under the background of high residential housing prices in Macau, this study has important theoretical and practical significance.

The remainder of the paper is structured as follows. Section 2 discusses literature review; Section 3 describes the data and hypotheses; Section 4 reviews the VAR model; Section 5 provides empirical test results, and Section 6 provides the conclusions and policy implications. 


\section{Literature Review}

In this section, I provide an overview of the literature on the interactions between house prices and economic variables as well as relationships between house prices and monetary policy.

\subsection{A Large Part of Extant Literatures Examining the Interaction between House Prices and Economic Variables}

Case and Shiller (2003) exam the housing affordability issue that is related to house prices-to-income ratio, a measure if the house is affordable to the average buyers. Black et al. (2006) develop an innovative way of computing the fundamental value of housing based on a time-varying present value of the real disposable income in the UK as the main factor that can affect the house prices. Using a dynamic present value model within a VAR framework to get market fundamental prices, Fraser et al. (2008) use a similar theory and methodology and confirm the house price in New Zealand is overvalued; Miller et al. (2007, 2009) provide the relationship between house prices and national wealth effect, and show the result for that there is a positive relationship between them. The national economy growth has a significant effect on the house prices. Costello et al. (2011) again use same present value model and find out there is deviation of actual price from its estimated fundamental prices spillover from cities over Australia. Typically, the above studies develop and exam the relationship between the house price prices and income determinants. Li and Chiang (2012) find that there are long term relationships among real estate price, CPI and GDP in China.

There are many house price literatures review about deriving the market fundamentals from an equilibrium model containing economic variables such as population, rent, stock of vacant new dwellings and land price etc. And house prices can be significantly influenced by these factors. Hui and Lui (2002) use economic variables as the land supply factor that can affect real house prices in HK. Using demand equals supply equation to construct the log-linear function between real houses prices and market fundamentals. Introducing the co-integration test and error correction model which is developed by Engle and Granger (1987) and widely used in the field of real estate industry; the test is used for examining the time series of variables to be integrated are of the same order. The empirical research concludes that there is a big gap between actual house prices and market fundamentals in HK. That means HK house market is more volatile than before. Furthermore, Hui and Shen (2006) measure the relationship between house prices and market fundamentals in three cities; they are Beijing, Shanghai and HK. In order to test the economic variables are correspondence with real estate house prices, the authors use more advanced econometric models to exam the casual relationship between house prices and market fundamental. They find there are differences between house prices and market fundamentals in HK and Shanghai. One important influence house price factor is the supply of land price. 
In urban areas, the supply of land is becoming scarce and the land price is becoming expensive. Deng et al. (2009) investigate what are the factors of fundamentals affect the house prices in China during the period of 2000-2005. They report that the house prices are significantly affected by real residential land prices.

Another house price measure approach is using the price-to-rent ratio, which is used for evaluating the cost of buying a house versus renting it. OECD (2005) evaluates price-to-rent ratios with the user cost of housing for the OECD economies from 1995 to 2005. In countries with high real house price gains during this period (UK, Ireland, the Netherlands, Spain, Australia and Norway), they conclude that actual price to rent ratios were above fundamental levels, suggesting there is overvaluation existed and it is cheaper to rent. Smith and Smith (2006) use a present value model to measure the market fundamentals. Buyers can decide that if the net present value is positive, the house is worth to buy; otherwise, renting would be better than owning a house. They also collect data about the pricing of buying a house or renting in US metropolitan cities. If price keeps increasing, the price-to-rent ratio should be higher its long-run average. This approach helps buyers to decide that the prices are too high relative to rent a house; the buyers will find advantages to rent a house rather than buying it.

\subsection{Literatures about the Impact between House Prices and Monetary Policy}

As indicated by the above summary of the fundamental house price literatures, the focus has typically been on various measures of "fundamentals". The impact between house prices and monetary policy is another important issue. In western countries, especially where the real estate market is relatively matured country, both academic and central bank have broadly pay attention to how the asset prices are influenced by monetary policy. (Mishkin, 2001, 2007; Iacoviello, 2005; Taylor, 2007, 2008, 2009) especially study the relationship between housing prices and monetary policy in USA, and they get the results that monetary policy can significantly affect house prices. Mishkin (2001) studies the relationship among monetary transmission mechanism and stock prices, real estate prices and foreign exchange rates. Except stock market price, the real estate price plays an important role in the monetary transmission mechanism too. The expansionary of monetary policy reduces interest rate, further reduces the cost of financing housing and therefore increases the house price. Mishkin (2007) uses the concept of user cost of capital, when interest rate increases the user cost of capital, it will cause a decline in housing demand and prices. As a result, the large run-ups in house price can seriously affect the financial instability, and monetary policy makers should respond to fluctuation of real estate price. There is empirical evidence on the link from monetary policy to residential prices. Using the structure VAR methodology, Iacoviello (2005) finds that the impact of monetary policy on real estate prices during 1974Q1 to 2003Q2. The author identifies 
the monetary policy has significant effect on house price through Impulse Response Model. Giuliodori (2005) provides some quantitative and qualitative evidence of the house price and monetary transmission mechanism across nine European countries. The paper presents the response of house prices to interest rates and the consumption as well. Using several VAR models, the author finds out the countries with more advantage of mortgage markets and efficient housing system, the relationship between interest rate and house prices will be stronger. Ahearne et al. (2005) study houses prices in 18 advanced economies and get results that confirm the link from monetary policy to housing prices. Therefore, booming in house prices are often preceded by a period of monetary policy loosening. Taylor (2007) also provides an early example of a study ascribing a large role to too loose monetary policy in USA, which means too low interest rate in spurring housing activity after the 2001 recession. Taylor (2008, 2009) increase suggesting that loose monetary policy is a primary cause of the bubble in house prices and activity. Dokko et al. (2009) review monetary policy rules from 2003 to 2006 in USA and argue that the loose monetary policy is not the primary contributing factor to the extraordinary strength in housing market of USA. The low interest rate is not strong enough to explain the rise in residential investment or increasing of house prices. In the wide selection of empirical papers, the majority researchers conclude the loose monetary policy is a primary cause of the bubble in house prices of western countries. Aizenman et al. (2016) use the dataset that covers 19 countries and find that the house price appreciations are positively linked with the expansionary monetary policy.

In recent years, especially after global financial crisis, more Chinese scholars have started concerning about the housing price in China and its impact factors. Liang and Cao (2007) study impact of monetary policy on house prices in China during 1999Q1-2006Q2. According to ARDL framework, the long-run relationship results show if the central government can imply long-term interest rate and bank credit instruments effectively into the real estate industry, they can control continue increasing of house prices. Kivu (2010) studies the wealth effect in China, using the VAR model, the loose monetary policy in China leads to higher asset prices, especially house prices. Yao et al. (2011) use monthly data from June 2005 to September 2010 in China to investigate the long-run relationship between monetary policy and asset prices. Using the VAR model, the empirical results show that monetary policy has little effect on residential prices, central bank and government should not only use interest rate to maintain the financial stability. There are many policies need to be concerned when dealing with asset bubbles. $\mathrm{Xu}$ (2017) examines the relationships among the house prices, interest rates, income and GDP growth rate in China, and find the control power of the interest rate for the prices is limited. The disposable income increases can increase the demand of houses. And the house price has positive relationship with GDP growth. Zhu et al. (2018) analyze the 35 major cities in China and find the impact of income on housing prices is positive, the interest 
rate is not significant impact on housing prices, and the population has significant impacted on housing prices. Wang et al. (2020) use the wavelet analysis method and find a positive co-movement between money supply growth and housing boom in China. Guo et al. (2020) find that expansionary monetary policy not only promotes total investment but simultaneously also leads to substitution towards financial assets.

\subsection{The Studying Literatures about Macau are Very Limited}

Comparing with large amount of research papers about western countries' and China's economic variables impact on house prices, the studying papers about Macau are very limited. There are only a few Chinese scholars' study about Macau real estate market in previous years, and published papers in journals. For example, Chen (2013a) studies the development process of Macau's real estate, analyzes that the reasons why Macau's housing price was always at a high level are because of the insufficient regulatory function of Macau's government and the imperfect housing security system. Finally, the paper expects that the government can promote the rational allocation of resources and fundamentally reverse the space-time situation of the market. Chen (2013b) mainly makes a qualitative analysis of the main factors of the real estate market price after Macau's return back to China, explains the relevant subsidies and policies in different periods, analyzes the bubble situation of the real estate in Macau, and then puts forward suggestions for regulation and control. Tang et al. (2015) use the multi-factor regression model to confirm various factors impact on the real estate prices in Macau; they use previous years' monthly data from January 2005 to August 2014 and prove that the unemployment rate, non-local employees and tourist arrivals have statistically significant relationship with the increasing of housing prices in Macau. Among them, the unemployment rate has a negative correlation with the housing price, while non-local employees and the number of tourists have a positive impact on the real estate price. Chen (2016) uses the VAR method and concludes that the gambling industry and the real estate industry in Macau are closely related from year 1996 to 2013. Gu et al. (2017) use 2005Q1 to 2015Q3 data to explain that the gaming growth leads to higher income inequality while at the same time both factors are responsible for soaring housing bubbles in Macau. Gu et al. (2020) also use VAR model to examine casino tourism expansion plays a fundamental role for both income inequality heightening and housing price hiking and confirms the income inequality can cause the housing bubbles in Macau. But they use quarterly data from year 2005 to 2015. The above papers use historical data to examine the real estate market situation in Macau in previous year.

Since there are still very limited English literatures examining the current real estate market situation in Macau and the empirical research paper requests to use the most recent years' data to do empirical test and show the evidence, in order to fill in this English literature gap and examine the situation of residential 
housing market of Macau in recent years, in the following research paper, I am going to use the recent years' (2005-2021) economics and monetary policy variables' monthly time-series data in section 3 to examine the residential housing value in Macau, the classical VAR model will be explained in section 4 and empirical results will be provided in section 5 . Also based on these results, I will provide conclusions and policy implications in section 6 as well.

\section{Data and Hypotheses}

The monthly data sources come from the Statistics and Census Service (DSEC) of Macau and QianZhan Database which are used to examine the long-term relationship among residential housing value, economic and monetary policy variables in Macau. The variables that I use in this study and their orders are the average residential housing value (HV), gambling gross income (Income), unemployment rate (UE), money supply (M2) and CPI. The sample time periods are from Jan. 2005 to May 2021.

Economic and monetary policy variables are obtained from QianZhan Database Company. Since the Statistics and Census Service (DSEC) provides numbers of residential housing and residential housing value, I use the residential housing value divided by the numbers of residential housing to calculate the average residential housing value in Macau. Figure 3 displays the monthly data of the average residential housing value in Macau from Jan. 2005 to May 2021.

From Figure 3, I can find that from Jan. 2005 to May 2015, the average residential housing value shows an increasing trend, which is correspondence with the previous content mentioned the booming GDP, increasing of gambling gross income, and visitors arrivals. But from May 2015 to March 2016, the housing price dropped down a lot since the central government of China changed the government

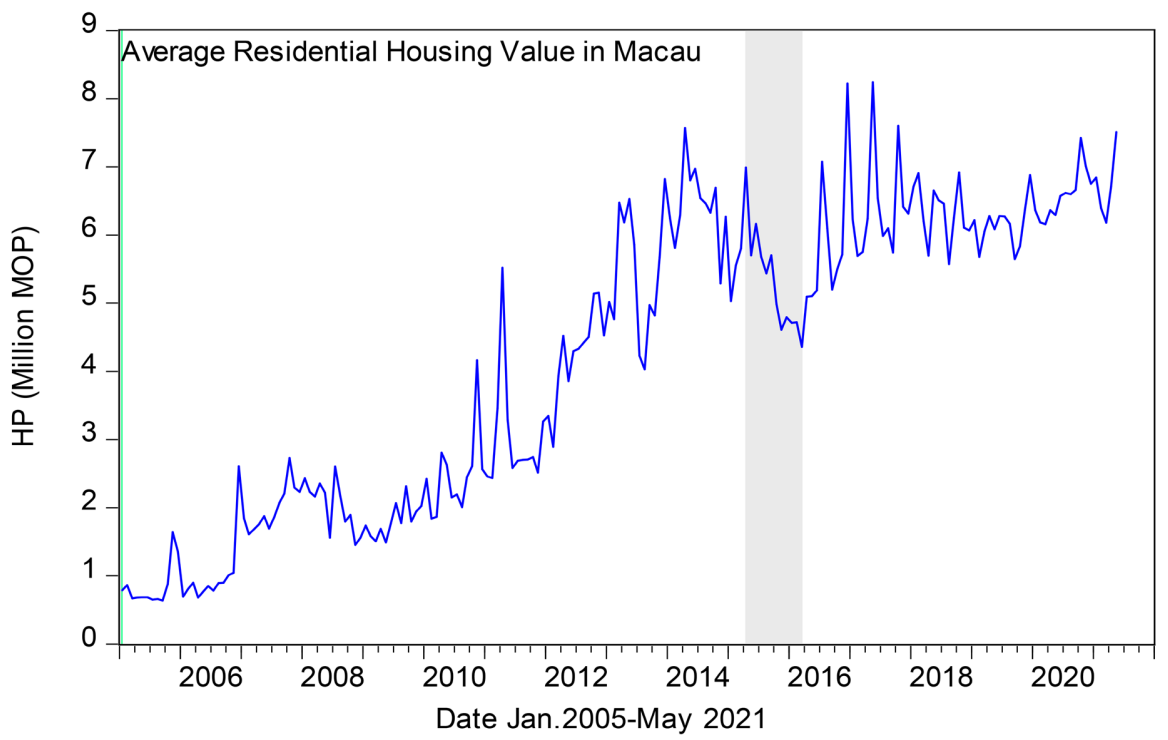

Figure 3. Macau's average residential housing value (Jan. 2005-May 2021). Source: Statistics and Census Service (DSEC) of Macau. 
policy to Macau. The GDP also decreased during that period (Figure 2). From year 2017 to 2021, the average residential housing value shows a stable trend.

Table 1 shows the summary statistics of these variables at monthly data frequency. The table provides the mean, standard deviation, maximum, minimum, and the measure of skewness and kurtosis. The negative skewness of residential housing value in Macau is around -0.72 , the kurtosis is around 3.49. It shows a non-normal distribution. The table also includes the summary statistics of other variables. In Jan. 2005, Macau has a historically high unemployment rate at $4.2 \%$, and after that the rapid economic growth makes the unemployment rate drops down to the lowest 1.7 in year 2014. But under the influence of the COVID-19 epidemic in 2020, the unemployment rose from 2\% to $3 \%$ between year 2020 to the first half of year 2021. The table shows the maximum unemployment rate is $4.2 \%$ and the minimum is $1.7 \%$. During the global financial crisis period, Macau has a very high inflation rate, the maximum rate reached to $8.7 \%$, but during the epidemic period, the inflation rate dropped down and turned to deflation rate at the lowest $-1.18 \%$ in Jan. 2021 .

Table 2 reports the correlations among these variables. From the table result, it can be seen that 1) the residential housing value has positive relationship with

Table 1. Descriptive Statistics

\begin{tabular}{cccccccc}
\hline Macau & N & Mean & Max & Min & SD & Skewness & Kurtosis \\
\hline LnHV & 197 & 8.05 & 9.86 & 5.7 & 0.70 & -0.72 & 3.49 \\
LnIncome & 197 & 9.50 & 10.55 & 6.64 & 0.78 & -1.14 & 3.98 \\
UE & 197 & 2.54 & 4.2 & 1.7 & 0.79 & 0.65 & 2.12 \\
LnM2 & 197 & 12.73 & 13.48 & 11.72 & 1.56 & -0.25 & 1.62 \\
CPI & 197 & 3.86 & 8.7 & -1.18 & 2.21 & -0.16 & 2.44 \\
\hline
\end{tabular}

Note: the table reports the summary statistics of the variables in this reseach paper. The data are obtained from the Statistics and Census Service (DSEC) and QianShan Database. The time-series data period starts from Jan. 2005 to May 2021. "N" is the number of data points. "Min" and "Max" are respectively the minimum and maximum data values. "S.D" is the standard deviation.

Table 2. Correlations among variables.

\begin{tabular}{cccccc}
\hline & LnHV & LnIncome & UE & LnM2 & CPI \\
\hline LnHV & 1 & 0.471 & -0.598 & 0.509 & -0.279 \\
LnIncome & 0.471 & 1 & -0.739 & 0.451 & 0.142 \\
UE & -0.598 & -0.739 & 1 & -0.839 & 0.043 \\
LnM2 & 0.509 & 0.451 & -0.839 & 1 & -0.407 \\
CPI & -0.279 & 0.142 & 0.043 & -0.407 & 1 \\
\hline
\end{tabular}

Note: Source the Statistics and Census Service (DSEC) and QianShan Database. The time-series data period starts from Jan. 2005 to May 2021. 
the gambling gross income, 2) it has negative relationship with the unemployment rate; 3) it has positive relationship with the money supply; and 4) it has negative relationship with the consumer price index. The results are consisted with the common sense but should be examined by the empirical model such as classical VAR system.

The residential housing value in Macau can be affected by many economic factors. Based on the availability of data from database and the correlation among variables from Table 2, this research paper provides the following four hypotheses.

$\mathrm{H1}$ : The gambling gross income has positive relationship with the residential housing value.

The contribution of gambling industry to Macau's economy is more than 70\% of the total GDP, and it has significant impact to Macau's economy. The city with the gambling industry as the main source of economic resources are short of natural resources and land resources, the main customers are not local residents, but a large number of non-local tourists. While the gambling industry in Macau is developing, it is also paying attention to improving the quality of catering, hotel and other service industries, which will also drive up the development of real estate industry. Through the empirical analysis of the impact of Macau's gambling industry on the real estate industry, it is known that the impact of Macau's gambling industry on the real estate industry is extremely high and has a positive role in driving the real estate industry, but the impact of real estate industry on Macau's gambling industry is very small. After returning to China and the legalization of the gambling industry, various kinds of foreign capital kept pouring in and luxury casinos are started built up, which greatly boosted the economic development of Macau. The housing price in Macau also kept soaring, and the residential housing value rose accordingly. The gambling industry has greatly developed Macau's economy, which led to the improvement of the living standard of Macau residents, and the demand for housing also increase.

H2: Unemployment rate has negative relationship with the residential housing value.

In Macau, a region lacking natural resources and land resources, the demand for real estate resources exceeds the supply and the price is relatively high. Moreover, residents' income level also determines residents' quality of life to some extent, and the increase of residents' quality of life will also increase people's demand for real estate, thus leading to the rise of the housing price. Under the influence of the global epidemic, the number of visitor arrivals in Macau has dropped sharply, the development of various industries in Macau has slowed or even stagnated, and the unemployment rate has also been rising. The unemployment rate has a negative impact on real estate industry, that is, the higher the unemployment rate is, and the lower the real estate value will be. People have no time to protect their own lives, and affect the confidence of in- 
vestment into the property, housing value will be fluctuated.

H3: The money supply has positive relationship with the residential housing value.

The monetary policy of Macau is to ensure that Macau has full currency convertibility and to expand the scope of exchange of Macau currency. The money supply mainly causes price changes by affecting the money market and the amount of money in circulation in the capital market. The cost of various materials and labor will also be changed. Finally, the real estate price will inevitably change accordingly. For the real estate industry, if investors find the real estate industry profitable, and the profit is considerable, it will attract many investments, and then cause the housing price to continue to rise. From the perspective of money supply, if there is excess money entering the market, the excess money will go to the industry with very considerable return rate, such as the real estate industry, which will lead to the rise of housing prices.

$\mathrm{H} 4$ : CPI has negative relationship with the residential housing value.

The consumer price index mainly reflects the price level and is usually used as a measure of inflation. Macau Consumer Price Index (CPI) is usually used to measure various price indexes in Macau, China. When the CPI increases too much, it indicates that inflation has become a destabilizing factor in the economy. Nowadays, with the development of economy and urbanization in Macau, houses have become a necessity for people. The rising house price leads to the decrease of people's consumption of other goods. A long period of rising house prices may be one reason for the CPI rise. However, after the impact of the epidemic in 2020, Macau's Inflation shows negative. This is the first time in nearly a decade that the inflation in Macau has turned from positive to negative which means the social price level has declined and shows a deflationary trend. it has also affected the residential housing value and caused some fluctuations.

\section{Research Method}

In order to know whether the time series of residential housing value and various proxies of economy and monetary policy variables are interacted and causality effect with each other. This paper uses the vector auto regression technique model that is suggested by (Sims, 1980) to predict the interconnected time series system and analyze the dynamic influence of random disturbance on variable system. The methodology has been widely used in many econometrics models in the field of real estate industry. For example, Chen and Patel (1998) use the VAR to investigate the house prices in Taiwan, Hui and Shen (2006) conduct stationary and Granger causality tests on three metropolitans house prices and economic variables in China.

The VAR model can be introduced in the following Equation (1):

$$
Y_{t}=A_{1} Y_{t-1}+A_{2} Y_{t-2}+A_{p} Y_{t-p}+\varepsilon, t=1,2, \cdots, n \text {. }
$$


In this Equation (1), $Y_{t}$ is a vector of the non-stationary variables and $A_{p}$ is the coefficient matrix which contains information about the relationships among these variables. The VAR model contains five variables: the residential housing value (LnHV), gambling gross income (LnIncome), unemployment rate (UE), money supply (LnM2) and CPI. The lag period of the model is determined according to the three information criteria (Akaike, Schwarz, and Hannan-Quinn). Except the unemployment rate and CPI, all the other variables are expressed in natural logarithms in order to dispel heteroskedasticity.

\section{Empirical Test Results}

\subsection{Unit Root Test Results}

I need to test the order of integration of the time series data. After many tests, I find the three information criteria are the smallest when the lag period is 4 . $\mathrm{Ta}$ ble 3 shows the results from the Phillips-Perron unit root tests, the number of lags (4) included in the tests was defined by the information criteria.

The results of PP test in Table 3 indicate that these variables are not stationary in level, which means have a unit root; but are stationary after first differencing. The test results show that all the time series variables are I (1).

Since the VAR model requires that the variable sequence are stable, I use the inverse roots of AR characteristic polynomial to test the stability again, it can be seen from the test in Figure 4 that the five unit roots are all in the circle, which shows the VAR system is stable.

Table 3. PP tests of the Variables in Macau, Jan. 2005-May 2021.

\begin{tabular}{|c|c|c|c|c|c|}
\hline Variables & $\begin{array}{c}\text { Test } \\
\text { statistics }\end{array}$ & $1 \%$ C.V. & $5 \%$ C.V & $10 \%$ C.V. & Stationary \\
\hline $\begin{array}{l}\text { LnHV } \\
\text { DLnHV }\end{array}$ & $\begin{array}{c}0.408 \\
-24.385\end{array}$ & -2.577 & -1.942 & -1.616 & $\begin{array}{l}\text { No } \\
\text { YES }\end{array}$ \\
\hline $\begin{array}{l}\text { LnIncome } \\
\text { DLnIncome }\end{array}$ & $\begin{array}{c}0.092 \\
-20.166\end{array}$ & -2.577 & -1.942 & -1.616 & $\begin{array}{l}\text { No } \\
\text { YES }\end{array}$ \\
\hline $\begin{array}{c}\text { UE } \\
\text { DUE }\end{array}$ & $\begin{array}{l}-1.281 \\
-11.643\end{array}$ & -2.577 & -1.942 & -1.616 & $\begin{array}{l}\text { No } \\
\text { YES }\end{array}$ \\
\hline $\begin{array}{l}\text { LnM2 } \\
\text { DLnM2 }\end{array}$ & $\begin{array}{c}6.879 \\
-13.924\end{array}$ & -2.577 & -1.942 & -1.616 & $\begin{array}{l}\text { No } \\
\text { Yes }\end{array}$ \\
\hline $\begin{array}{c}\text { CPI } \\
\text { DCPI }\end{array}$ & $\begin{array}{l}-1.098 \\
-14.496\end{array}$ & -2.577 & -1.942 & -1.616 & $\begin{array}{l}\text { No } \\
\text { Yes }\end{array}$ \\
\hline
\end{tabular}

Note: Four variables are used as the proxies for economic and monetary policy variables: gambling gross income, unemployment rate, money supply and consumer price index. The corresponding critical values for a model without trend and intercept for PP unit root tests are $-2.577,-1.942$, and -1.616 at the 1,5 , and 10 percent significance level, respectively. 


\subsection{Granger Causality Test Results}

Under the VAR system, Table 4 concludes that all variables have predictive power for housing prices in Macau. Each variable is the Granger cause of residential housing value when its lag behinds the first order. For the null hypothesis that gambling gross income does not Granger cause residential housing value, the null hypothesis is rejected with the $\mathrm{P}$ value at 0.034 . It can be explained that the residential housing value is due to the gambling gross income; while the residential housing value is not the cause of the gambling gross income. There is a one-way causality from gambling gross income to residential housing value in

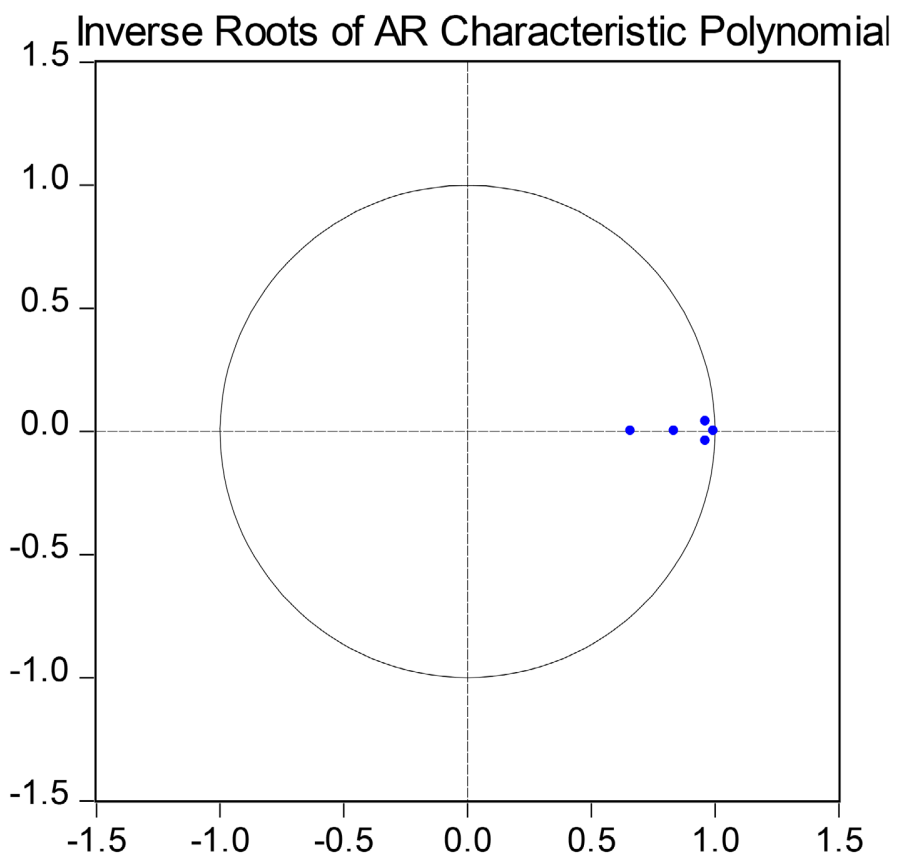

Figure 4. Inverse roots of AR characteristic polynomial. Source: Statistics and Census Service (DSEC) of Macau and QianZhan Database.

Table 4. Pair-wise granger causality test results.

\begin{tabular}{cccc}
\hline Cause $\rightarrow$ Effect & F-Statistics & P Value & Results Cause $\rightarrow$ Effect \\
\hline Lnincome $\rightarrow$ LnHV & 2.263 & 0.034 & YES \\
LnHV $\rightarrow$ Lnincome & 2.776 & 0.097 & No \\
UE $\rightarrow$ LnHV & 6.625 & 0.011 & YES \\
LnHV $\rightarrow$ UE & 9.841 & 0.002 & YES \\
LnM2 $\rightarrow$ LnHV & 5.943 & 0.016 & YES \\
LnHV $\rightarrow$ LnM2 & 1.193 & 0.276 & No \\
CPI $\rightarrow$ LnHV & 3.231 & 0.074 & YES \\
LnHV $\rightarrow$ CPI & 1.193 & 0.276 & No
\end{tabular}

Note: Source the Statistics and Census Service (DSEC) and QianShan Database. The time-series data period starts from Jan. 2005 to May 2021. 
Macau. This empirical result is the same as the research paper of Chen (2016). Also, there is one-way causality from money supply to residential housing value and one-way causality from consumer price index to residential housing value as well. Based on the tests results, there is only a two-way causality from unemployment rate to residential housing value in Macau.

\subsection{Impulse Response Function Results}

I want to know the interconnected relationship among these variables, and the level of impact, one of the methods is to analyze the case when a disturbance term is changed or when the model is hit by some sorts of shock, what the dynamic effects of the system will be, and this method is called the impulse response function method. It explains the positive and negative directions of the response, the adjustment of the time delay and the stability process generated by the impact of the system. The impulse response functions results are shown in Figures 5-8.

As shown in Figure 5, there is evidence that the gambling gross income has positive impact on residential housing value. Positive impacts on gambling gross income are described to increase the residential housing value for up to more than 12 periods. This graph result confirms the hypothesis 1 .

As shown in Figure 6, it indicates clearly that the unemployment rate has negative impact on residential housing value. Negative impacts on unemployment rate are described to decrease the residential housing value for up to more than 12 periods. This graph result confirms the hypothesis 2 .

As shown in Figure 7, the graph indicates in the longer trend, after 10 periods, the money supply has positive impact on residential housing value. Since money supply is a very important monetary policy instrument as mentioned before in this research paper, it takes time to invest in the real estate industry,

\section{Response of LNHV to LNINCOME Innovation}

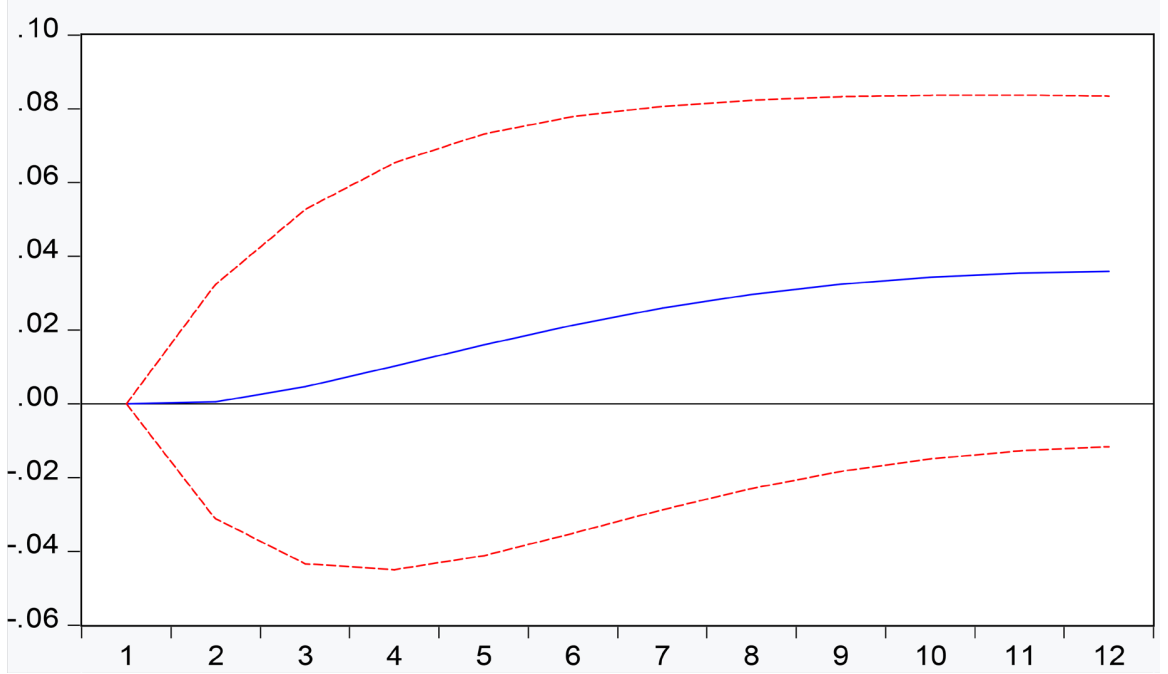

Figure 5. Response of LnHV to lnIncome innovation. 
Response of LNHV to UE Innovation

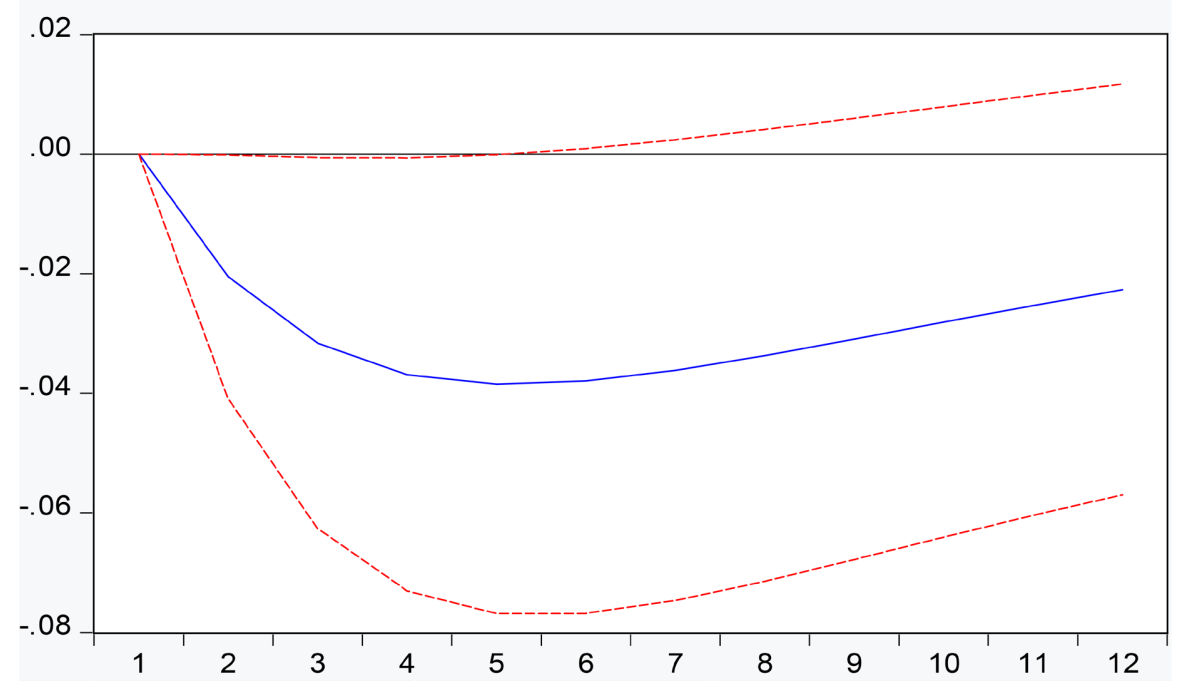

Figure 6. Response of LnHV to UE innovation.

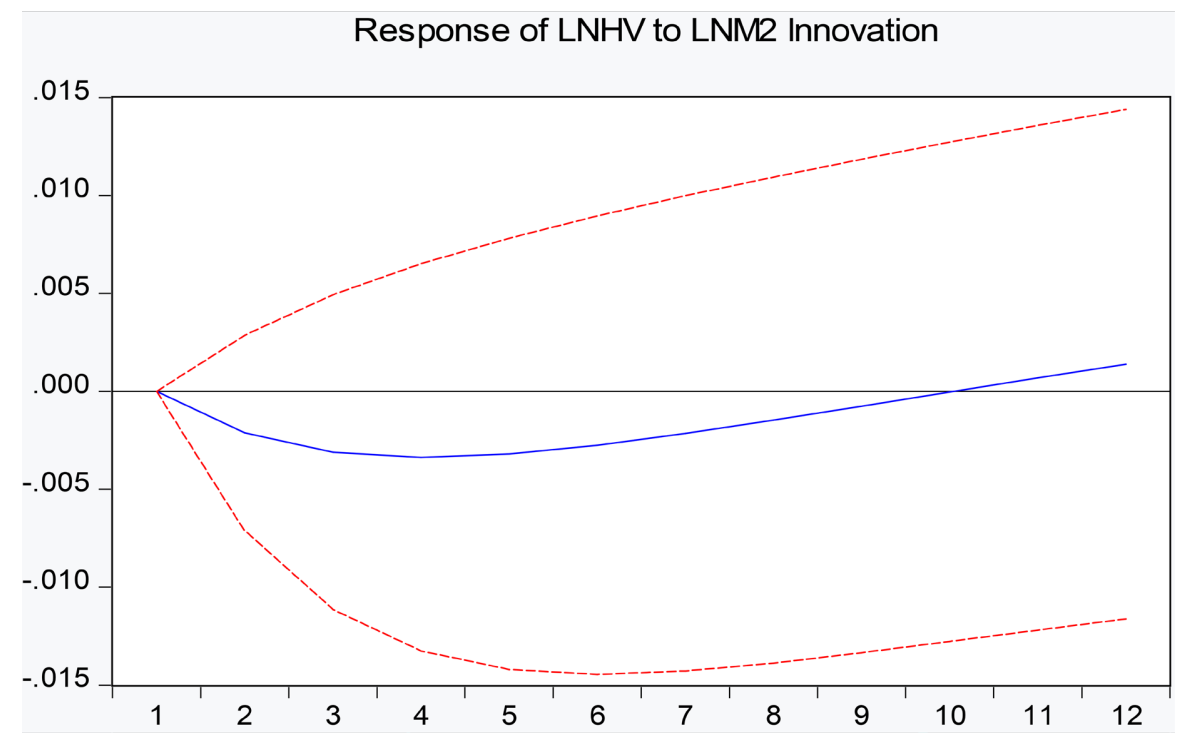

Figure 7. Response of LnHV to LnM2 innovation.

therefore, it shows a lagged impact. But for a long time period, the graph result shows it has positive impact on residential housing value. The graph result confirms the hypothesis 3.

As shown in Figure 8, it indicates clearly that the consumer price index has negative impact on residential housing value. Negative impacts on consumer price index are described to decrease the residential housing value for up to more than 12 periods. This graph result confirms the hypothesis 4 .

\subsection{Forecast Error Variance Decomposition Results}

The forecast error variance decomposition method is to evaluate the importance of different structural shocks by analyzing the contribution of each structural 


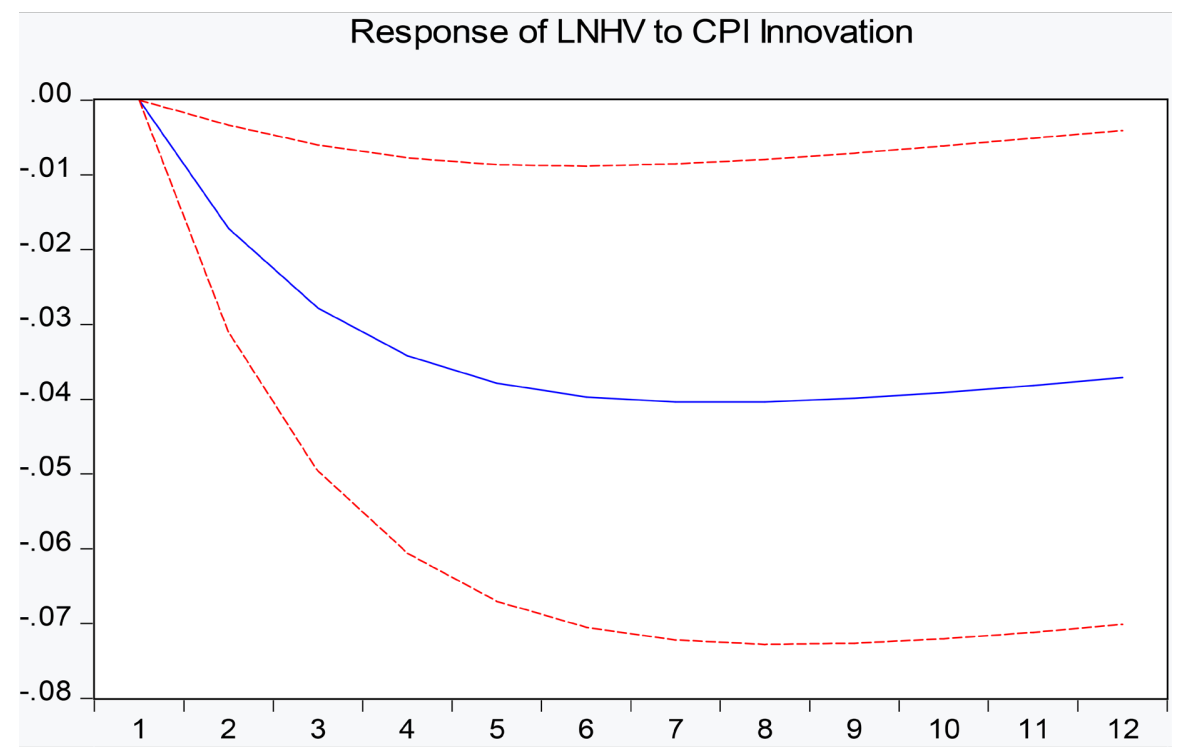

Figure 8. Response of LnHV to CPI innovation.

Table 5. Results of variance decomposition test.

\begin{tabular}{ccccccc}
\hline \multirow{2}{*}{$\begin{array}{c}\text { Forecast } \\
\text { Horizon }\end{array}$} & \multicolumn{5}{c}{ Variance Decomposition of Residential Housing Value } \\
\cline { 2 - 7 } & LnHV & LnIncome & UE & LnM2 & CPI & Total \\
\hline 2 & 99.377 & 0.239 & 0.049 & 0.061 & 0.273 & 100 \\
5 & 73.819 & 2.441 & 2.734 & 14.917 & 1.778 & 100 \\
10 & 58.990 & 2.850 & 4.672 & 25.938 & 7.550 & 100 \\
12 & 55.364 & 2.678 & 5.664 & 28.502 & 7.792 & 100 \\
\hline
\end{tabular}

Note: The table reports the variance decomposition after 2, 5, 10 and 12 lags for residential housing value and other variables under shock to residential housing value.

shock to the change of variables. Variance decomposition results are shown in Table 5. It can be observed that the contribution of residential housing value in the $2^{\text {nd }}$ period is affected its own shock for $99.377 \%$. As the period increases to $12^{\text {th }}$ period, the variance in shock to residential housing value is affected by its own shock decreases to $55.364 \%$, money supply accounts for $28.502 \%$ of the residential housing value variance, showing that money supply is powerful in affecting housing value. CPI and unemployment rate also shows increasing shocks to residential housing value. These results are consistent completely with the findings from Granger causality test result and impulse response function test results.

\subsection{Co-Integration Test Result}

From the previous analysis results, all the variables are integrated in order 1 , they satisfy the condition of co-integration test, I use Johansen and Juselius (1990) co-integration test to examine the relationship among these variables. The null hypothesis of the maximum eigenvalue test is that there are at most $r$ 
co-integrating vectors. The null hypothesis of the trace test is that the number of co-integrating vectors is less than or equal to $r$.

When applying the co-integrating test, all the variables in the VAR model should be non-stationary. Table 3 reports that all the variables have unit roots at their levels. Table 6 shows the results for the rank tests results by using co-integration method. The tests are based on 1 lag for the entire period. The results show that there are at least two cointegration equations among these variables. Both trace statistics test and maximum eigenvalue test reject the null hypothesis of $\mathrm{r}$ less than 1 at the $5 \%$ significance level, therefore, the null hypothesis of no integration is rejected by both the trace and max-eigenvalue statistics at the $5 \%$ significance value. The results show the residential housing value and the economic and monetary variables are co-integrated over the entire period. This implies that there is a long-run relationship between residential housing value in Macau and its determinants.

To sum up, based on the VAR model and its test methods, I use the time series data from Jan. 2005 to May 2021, and obtain the following results.

The gambling gross income has significant positive relationship with the residential housing value. Currently, the gambling industry in Macau continues to decline, in this background, the future development of the real estate industry will be greatly affected too. This result is consistent with the research papers of Gu et al. (2017, 2020). Unemployment rate has significant negative relationship with the residential housing value. Based on the data source from QianZhan Database, the average unemployment rate from March to June 2021 is $2.9 \%$. The local citizen unemployment rate in June 2021 increased to 3.9\%. By industry, gambling agencies and hotels are the main source of unemployment in Macau. As can be seen from the data, there is a lag in the real estate market. Under the influence of the rising unemployment rate, the housing value in Macau has generally decreased. Among them, the high residential housing value in May was

Table 6. Johansen and Juselius tests for co-integration relation, Jan. 2005-May 2021.

\begin{tabular}{cccccccc}
\hline $\begin{array}{c}\text { Time } \\
\text { Series }\end{array}$ & Lags & $\begin{array}{c}\text { Trace } \\
\text { Statistics }\end{array}$ & Rank & $\mathbf{5 \%}$ C.V. & $\begin{array}{c}\text { Max } \\
\text { Statistics }\end{array}$ & Rank & $\mathbf{5 \% ~ C . V . ~}$ \\
\hline LnHV & 1 & 117.51 & $0^{*}$ & 69.82 & 58.21 & $0^{*}$ & 33.88 \\
LnIncome & (AIC, & 59.30 & $1^{*}$ & 47.86 & 38.47 & $1^{*}$ & 27.58 \\
UE & HQ, & 20.83 & 2 & 29.79 & 11.34 & 2 & 21.13 \\
LnM2 & SBIC) & 9.49 & 3 & 15.49 & 8.01 & 3 & 14.26 \\
CPI & & 1.48 & 4 & 3.84 & 1.48 & 4 & 3.84 \\
\hline
\end{tabular}

Note: 1 lag is used in all the co-integration vectors based on three information criteria. The null hypothesis in which there exists at more $\mathrm{r}$ co-integration vectors in the system. The co-integration tests are done under the assumption of a trend in data and an intercept and trend in the co-integration eq. C.V. (5\%) is the critical value of the trace statistics and maximium eigenvalue statistics for cointegration tests. ${ }^{*}$ indicates significant at the $5 \%$ level. 
due to the recovery of the epidemic, the market rebound, and the accumulation of months of housing demand concentrated burst. The money supply has significant positive relationship with the residential housing value. In recent years, major cities in the Guangdong-Hong Kong-Macau Greater Bay Area have been closely linked and restrictions on household registration have been relaxed, which has continuously stimulated market vitality. The good and harmonious social atmosphere has accelerated the introduction of foreign investment in Macau, and investors have invested and bought property in Macau. Macau's economy has a good momentum of development, the related industries have been reasonably developed, and the active housing transactions have led to the rise of housing values. CPI has significant negative relationship with the residential housing value. Due to the impact of the epidemic, the Composite price index of Macau has dropped for twelve consecutive months from January's $2.98 \%$ to December's $-0.87 \%$ in year 2020 , and it has been continuing showing a deflation trend in the first half year of 2021. Since the CPI shows a deflationary trend. The cost of raw materials for housing construction has decreased, leading to the fluctuation of housing values. It is not hard to be seen from the QianZhan database that the consumer price index has a bigger negative impact on housing value. Deflation will make enterprises hard to withdraw funds and increase the risk of bad debts; Household incomes are falling, and dampening consumer demand. A long period of deflation may lead to the instability of the economy, the government is actively taking measures to avoid this situation, CPI may go back up soon, the real estate industry will keep heating up.

\section{Conclusion and Policy Implications}

Based on the above summary, in order to promote the healthy development of the real estate industry in Macau, I put forward the following five suggestions.

First, appropriately guide the development of the real estate industry in Macau since the return of Macau and the opening of gambling rights, a large number of foreign capital poured into Macau, which led to the continuous rise of housing prices in Macau, leading to the rise of prices and the increase of people's living costs. As one of the four basic industries in Macau, real estate plays an unshakable role in Macau's economic development. The government of the Macau special administrative region should continue to encourage and support the development of the real estate industry, perfect the relevant management system of the industry, guide the real estate industry diversification development, foster the development of new industrial chain, reduce the risk of real estate enterprise capital chain break up and promote the sustainable and healthy development of the real estate industry in Macau.

Second, to strengthen Macau's cooperation with the mainland, the construction of the greater Bay Area urban agglomeration has given investors confidence to invest in it. At present, Macau, Zhuhai and even the Pearl River Delta region are integrated into industries and rely on each other economically. A better 
mainland economy will accelerate the pace of Macau's economic progress. To strengthen in-depth cooperation with the mainland is an inevitable trend of development, it is the common aspiration of the people in Macau and the mainland and a necessary requirement for promoting economic diversification in Macau. Because of the COVID-19 spread and Macau's economy has been facing decreasing, the CPI shows a deflation trend. In order to rebound the real estate industry and improve the quality of life of the residents, the Macau government can allow cross-border real estate investment for Macau citizens. And allow them to use the house mortgage loan in Macau to invest real estate market in Zhuhai, China.

Third, it is rectifying the financial market and standardizing bank credit services. At present, the residential housing price in Macau is still a heavy burden for ordinary families. As shown in Figure 3, the average residential housing value is 7 million Patacas in Macau and equals more than 5 million RMB. Most of the families buy a property through mortgage loans. The Macau monetary authority report shows that the average housing mortgage loan is between 4 million Patacas to 6 million Patacas in the first quarter of the year 2021, which occupies $39.1 \%$ of all the mortgage loans. Therefore, the Macau government should enhance the management of the financial market, strengthen the supervision of commercial banks and improve the risk prevention and control mechanism. At the same time, commercial banks should strengthen their awareness of risk prevention, strictly examine the credit of loan officers, and regulate real estate credit services.

Fourth, it is to control regional economy and justify monetary policy. With the continuous development of China's real estate economy and the continuous completion of the Guangdong-Hong Kong-Macau Greater Bay Area urban agglomeration, the housing price transmission mechanism between cities will become stronger and stronger. The central government of China should continue improving the economic system of the real estate market in the Greater Bay Area, focusing on economic regulation, strengthening economic linkage among different regions and avoiding direct intervention in local economic development. In addition, the central government can adopt monetary policies corresponding to the economy according to the different market conditions. Especially in 2020, when the epidemic is rampant, all industries are affected by varying degrees. Appropriate expansionary monetary policy can reduce the impact of the epidemic, improve the job market and increase the employment rate; at the meantime, it can lower the savings interest rate, stimulate residents' consumption, and make people shift their investment focus to the real estate industry and improve people's living standard.

Finally, it is to vigorously develop tourism and the gambling industries. The year 2020 is difficult. Not only Macau, but all human beings across the country have suffered a great recession. The recovery of the national economy has become a major focus of current development. Therefore, while ensuring the pre- 
vention and control of the epidemic, the tourism industry should be reasonably developed to attract tourists to Macau, the development of the gambling industry should be restored, and the employment rate of Macau's population should be correspondingly increased. For example, the recent decreases in the tourist price index and hotel room prices in Macau have to some extent stimulated the consumption of tourists in Macau. And Grand Lisboa Palace Resort is opened on July $31^{\text {st }}, 2021$, which attracts more visitors' attention. If the epidemic is fully under control and disappears, Macau's economy will surely be recovered, and the real estate industry will also achieve good development as well.

\section{Acknowledgements}

This research paper was presented in front of my Supervisor and committee members at University of Macau before; they gave me some comments and suggestions. Therefore, I would like to thank Professor Jacky SO, Professor Rose Lai, Professor Zhang Yang, Professor Maggie Fu, and Professor Yuan Jia. They gave me helpful comments and suggestions on the earlier version of the manuscript. I also need to thank anonymous reviewer and editor who provide detailed suggestions to my manuscript and let me improve it in order to meet the journal publishing requirement. The author is grateful for financial support from Beijing Institute of Technology, Zhuhai.

\section{Conflicts of Interest}

The author declares no conflicts of interest regarding the publication of this paper.

\section{References}

Ahearne, A. G., Ammer, J., Doyle, B. D., Kole, L. S., \& Martin, R. F. H. (2005). House Prices and Monetary Policy: A Cross-Country Study. International Finance Discussion Papers. No. 841, Board of Governors of the Federal Reserve System. https://doi.org/10.17016/IFDP.2005.841

Aizenman, J., Jinjarak, Y., \& Zheng, H. (2016). House Valuations and Economic Growth: Some International Evidence. Working Paper No. 22699, National Bureau of Economic Research. https://doi.org/10.3386/w22699

Black, A., Fraser, P., \& Hoesli, M. (2006). House Prices, Fundamentals and Bubbles. Journal of Business, Finance \& Accounting, 33, 1535-1555. https://doi.org/10.1111/j.1468-5957.2006.00638.x

Case, K. E., \& Shiller R. J. (2003). Is there a Bubble in the Housing Market? Brookings Papers on Economic Activity, 2003, 299-342. https://doi.org/10.1353/eca.2004.0004

Chen, M. C., \& Patel, K. (1998). House Price Dynamics and Granger Causality: An Analysis of Taipei New Dwelling Market. Journal of the Asian Real Estate Society, 1, 101-126.

Chen, R. P. (2013a). Macao Real Estate Market Analysis and Regulation Voice. South China University of Technology.

Chen, W. B. (2013b). Analysis on the Trend of Macao Real Estate Market. Foreign In- 
vestment in China, 24, 92-93.

Chen, Z. X. (2016). An Empirical Analysis of the Impact of Macau Gambling Industry on Real Estate Industry. Hong Kong and Macao Research, 3, 84-92.

Costello, G., Fraser, P., \& Groenewold, N. (2011). House Prices, Non-Fundamental Components and Interstate Spillovers: The Australian Experience. Journal of Banking \& Finance, 35, 653-669. https://doi.org/10.1016/j.jbankfin.2010.07.035

Deng, C. R., Ma, Y. K., \& Chiang, Y. M. (2009). The Dynamic Behavior of Chinese Housing Prices. International Real Estate Review, 12, 121-134.

https://doi.org/10.53383/100108

Dokko, J., Doyle, B., Kiley, M. T., Kim, J., Sherlund, S., Sim, J., \& Heuvel, S. V. D. (2009). Monetary Policy and the Housing Bubble. Board of Governors of the Federal Reserve System. https://doi.org/10.17016/FEDS.2009.49

Engle, R. F., \& Granger, C. W. J. (1987). Cointegration and Error Correctionn: Representationn, Estimation and Testing. Econometrica, 55, 251-276.

https://doi.org/10.2307/1913236

Fraser, P., Hoesli, M., \& McAlevey, L. (2008). House Prices and Bubbles in New Zealand. The Journal of Real Estate Finance and Economics, 37, 71-91. https://doi.org/10.1007/s11146-007-9060-8

Giuliodori, M. (2005). The Role of House Prices in the Monetary Transmission Mechanism across European Countries. Scottish Journal of Political Economy, 52, 519-543. https://doi.org/10.1111/j.1467-9485.2005.00354.x

Gu, X. H., Li, G. Q., Chang, X., \& Guo, H. Z. (2017). Casino Tourism, Economic Inequality, and Housing Bubbles. Tourism Management, 62, 253-263. https://doi.org/10.1016/j.tourman.2017.04.006

Gu, X. H., Li, G. Q., Lei, C. K., Li, S., \& Zhao, Q. B. (2020). The Inequality-Housing Price Nexus in Tourist Resorts: Theory and Evidence. Asia-Pacific Journal of Accounting and Economics, 27, 132-150. https://doi.org/10.1080/16081625.2020.1686842

Guo, Y., Huang, X., \& Peng, P. (2020). How Does House Price Influence Monetary Policy Transmission? International Review of Financial Analysis, 72, Article ID: 101595. https://doi.org/10.1016/j.irfa.2020.101595

Hui, E. C. M., \& Shen, Y. (2006). Housing Price Bubbles in Hong Kong, Beijing and Shanghai: A Comparative Study. Journal of Real Estate Finance and Economics, 33, 299-327. https://doi.org/10.1007/s11146-006-0335-2

Hui, E., \& Lui, T. Y. (2002). Rational Expectations and Market Fundamentals: Evidence from Hong Kong's Boom and Bust Cycles. Journal of Property Investment \& Finance, 20, 9-22. https://doi.org/10.1108/14635780210416237

Iacoviello, M. (2005) House Prices, Borrowing Constraints, and Monetary Policy in the Business Cycle. American Economic Review, 95, 739-764. https://doi.org/10.1257/0002828054201477

Johansen, S., \& Juselius, K. (1990). Maximum Likelihood Estimation and Inference on Cointegration-With Application to the Demand for Money. Oxford Bulletin of Economics and Statistics, 52, 169-210. https://doi.org/10.1111/j.1468-0084.1990.mp52002003.x

Kivu, T. (2010). Monetary Policy, Asset Prices and Consumption in China. Working Paper Series No. 1240, European Central Bank. https://doi.org/10.2139/ssrn.1703371

Li, J., \& Chiang, Y. H. (2012). What Pushes Up China's Real Estate Price? International Journal of Housing Markets and Analysis, 5, 161-176. 
Liang, Q., \& Cao, H. (2007). Property Prices and Bank Lending in China. Journal of Asian Economics, 18, 63-75. https://doi.org/10.1016/j.asieco.2006.12.013

Miller, N., \& Liang, P. (2007). House Prices and Economic Growth. Working Paper, University of Colorado.

Miller, N., Liang, P., \& Sklarz, M. (2009). House Prices and Economic Growth. Journal of Real Estate Finance and Economics, 42, 522-541. https://doi.org/10.1007/s11146-009-9197-8

Mishkin, F. S. (2001). The Transmission Mechanism and the Role of Asset Prices in Monetary Policy. Working Paper Series No. 8617, National Bureau of Economic Research. https://doi.org/10.3386/w8617

Mishkin, F. S. (2007). Housing and the Monetary Transmission Mechanism. NBER Working Paper Series No.13518, National Bureau of Economic Research. https://doi.org/10.3386/w13518

OECD (Organisation for Economic Co-Operation and Development) (2005). Recent House Price Development: The Role of Fundamentals. Economic Survey of Eighteen Countries. OECD Economic Outlook, 2002, 123-154. https://doi.org/10.1787/eco_outlook-v2005-2-38-en

Sims, C. A. (1980). Macroeconomics and Reality. Econometrica, 48, 1-48. https://doi.org/10.2307/1912017

Smith, M. H., \& Smith, G. (2006). Bubble, Bubble, Where's the Housing Bubble? Brookings Papers on Economic Activity, 1, 1-67. https://doi.org/10.1353/eca.2006.0019

Tang, X. H., Zhang, Y., \& Chen, J. B. (2015). Determinants of Real Estate Prices in Macao. Real Estate Guide, No. 13, 31, 35.

Taylor, J. B. (2007). Housing and Monetary Policy. Working Paper Series No. 13682, National Bureau of Economic Research. https://doi.org/10.3386/w13682 https://www.nber.org/papers/w13682.pdf

Taylor, J. B. (2008). The Financial Crisis and the Policy Responses: An Empirical Analysis of What Went Wrong. Speech delivered at a Festschrift in Honor of David Dodge's Contributions on Canadian Public Policy at the Bank of Canada.

Taylor, J. B. (2009). The Financial Crisis and the Policy Responses: An Empirical Analysis of What Went Wrong. NBER Working Paper Series No. 14631, National Bureau of Economic Research. https://doi.org/10.3386/w14631 https://www.nber.org/papers/w14631

Wang, X. Q., Hao, L. N., Tao, R., \& Su, C. W. (2020). Does Money Supply Growth Drive Housing Boom in China? A Wavelet-Based Analysis. Journal of Housing and the Built Environment, 35, 125-141. https://doi.org/10.1007/s10901-019-09668-w

$\mathrm{Xu}, \mathrm{T}$. (2017). The Relationship between Interest Rates, Income, GDP Growth and House Prices. Research in Economics and Management, 2, 30-37. https://doi.org/10.22158/rem.v2n1p30

Yao, S. J., Luo, D., \& Loh, L. X. (2011). On China's Monetary Policy and Asset Prices. Discussion Paper No. 71. The University of Nottingham, China Policy Institute. https://doi.org/10.2139/ssrn.1788064

Zhu, H. M., Li, Z., \& Guo, P. (2018). The Impact of Income, Economic Openness and Interest Rates on Housing Prices in China: Evidence from Dynamic Panel Quantile Regression. Applied Economics, 50, 4086-4098.

https://doi.org/10.1080/00036846.2018.1441512 